\title{
Drones, Automated Weapons, and Private Military Contractors
}

\section{Challenges to Domestic and International Legal Regimes Governing Armed Conflict}

\author{
Laura A. Dickinson **
}

\section{INTRODUCTION}

The development of unmanned aerial vehicles and increasingly autonomous weapons systems is radically reshaping the nature of modern warfare. The US military now depends on unmanned aerial systems, often referred to as drones, to provide intelligence and surveillance, while armed drones that can drop bombs on terrorists form a core part of the US arsenal in the war on terror. From the longstanding Phalanx system, deployed by the US Navy to automatically detect and neutralize missiles that breach a warship's protective envelope, to the Counter Rocket, Artillery, and Mortar (C-RAM) system, the US Army's comparable landbased defense, to the $\mathrm{X}-47 \mathrm{~B}$ drone that can fly by itself during takeoff and landing, the United States has relied increasingly on weapons systems that are unmanned or have at least some autonomous capability. Other countries have developed such systems as well, from Israel's Harpies, which autonomously ferret out enemy radar and then dive-bomb to destroy them, to South Korea's robotic sentries protecting the border. ${ }^{1}$

In addition to altering the nature of warfare on the ground and in the air, the use of these new weapons systems has shaken up existing legal frameworks, both domestic and international, regulating the use of force abroad. Scholars and policy-makers have frequently grappled with the legal implications of deploying unmanned vehicles and increasingly autonomous weapons systems. ${ }^{2}$ For example, some have discussed the legality of US efforts to target individual terrorists for

* Thanks to Bryan Cenko and Jiyoon Moon for useful research assistance.

1 For a discussion of these systems, see text and notes below.

2 J. Elsea, Legal Issues Related to the Lethal Targeting of U.S. Citizens Suspected of Terrorist Activities (CRS Legal Memorandum) (Washington, DC: Congressional Research Service, 2012), https://perma.cc/M26G-PR2W. 
assassination, often through drone strikes. ${ }^{3}$ Others have focused specifically on the question of whether such targeted killings can be justified anywhere outside the battlefields of Afghanistan and Iraq. ${ }^{4}$ Still others debate whether drones are worse (or better) than conventional weapons at limiting civilian casualties. ${ }^{5}$

Drones and automated weapons also raise broader questions about the asymmetry inherent in this sort of warfare, where one side has few if any casualties and the other is subject to multiple strikes without an effective way to respond. Such asymmetry, some argue, violates fundamental principles of humanity undergirding the entire body of International Humanitarian Law (IHL). ${ }^{6}$ Finally, debates under US domestic law focus

3 See, e.g., J. Daskal, "The Geography of the Battlefield: A Framework for Detention and Targeting Outside the Hot Conflict Zone" (2013) 161(5) University of Pennsylvania Law Review 1165-234 (surveying approaches of legal scholars); A. Hudson, "Beyond the Drone Debate: Should US Military and CIA Be Judge, Jury, and Executioner?” Truthout, June 2, 2015, https:// perma.cc/8EE4-4FEK (discussing reactions by the legal world, noting that Philip Alston, Christof Heyns, and Naz Modirzadeh have condemned drone strikes as outside the norms of international humanitarian law).

4 See, e.g., M. O'Connell, "Unlawful Killing with Combat Drones: A Case Study of Pakistan 2004-2009," in S. Bonitt (ed.), Shooting to Kill: The Law Governing Lethal Force in Context (London: Hart Publishing, 2012) (arguing that drone strikes are not a lawful use of force, that there is no armed conflict in Pakistan, and that drones are ineffective at killing only the intended target); see also Daskal, "The Geography of the Battlefield."

5 For example, some suggest that tallies undercount civilian casualties and that civilians are being unnecessarily sacrificed in failed attempts to reach terrorists. See, e.g., C. Friedersdorf, "Flawed Analysis of Drone Strike Data Is Misleading Americans," The Atlantic (July 18, 2012), https://perma.cc/PEY3-DTLB; "You Never Die Twice: Multiple Kills in the US Drone Program," Reprieve, https://perma.cc/KVY6-8UZ8. Others argue that the numbers of civilian casualties have dropped as targeting technologies have improved. See P. Bergen and J. Rowland, "Civilian casualties plummet in drone strikes," CNN, July 14, 2012, https:// perma.cc/ZT4X-8M6G. Overall, the New America Foundation has calculated that Pakistani casualties ranged between 2,003 and 3,321 from 2004 to April 2013. See P. Bergen, Drone Wars: The Constitutional and Counterterrorism Implications of Targeted Killing: Testimony presented before the U.S. Senate Committee on the Judiciary, Subcommittee on the Constitution, Civil Rights and Human Rights, 113th Cong. (2013) (testimony of Peter Bergen, director of the National Security Studies Program, New America Foundation), https://perma.cc/64HV-BgAE. In Yemen, where the number of drone strikes has increased, estimates of civilian casualties in 2013 range from 467 to 674 , the vast majority of which occurred under the Obama administration. See Bergen, Drone Wars. In late 2013, a drone strike mistakenly attacked a wedding party in Yemen, killing numerous unarmed civilians. See J. Serle, "American drone suspected in wedding-day massacre," Salon, December 16, 2013, https://perma.cc/FWF6-87FJ. And in April 2015, the United States government was forced to admit that two civilians had been killed as a result of a mistaken drone strike. See J. Diamond, "U.S. drone strike accidentally killed 2 hostages," CNN, April 23, 2015, https://perma.cc/S6KF-2E73.

6 See generally R. Sparrow, "War Without Virtue?" in B. Strawser (ed.), Killing by Remote Control (Oxford: Oxford University Press, 2013) (questioning the effects drone warfare will have on the military); B. Strawser, "Moral Predators: The Duty to Employ Uninhabited Aerial Vehicles" (2010) 9(4) Journal of Military Ethics 342-68 (arguing that drones are justified because they allow for greater protection of the military, providing that the drones do not interfere with the military's ability to make just judgment calls); J. McMahan, "The Ethics of Killing in War" (2004) 114(4) Ethics 693-733 (arguing that combatants fighting with an unjust cause require no reciprocity morally, so the drone program violates no ethics); J. McMahan, 
largely on whether the Constitution can be invoked extraterritorially to protect the rights of citizens (or even noncitizens) targeted in such strikes, given that so far individuals have only been targeted while outside the territorial borders of the United States. ${ }^{7}$

Concurrent with this trend toward the use of weapons that are more autonomous, the United States and many other countries have also privatized a broad array of military and security functions, using private contractors to an arguably unprecedented degree. ${ }^{8}$ For example, at the high point of the conflict in Iraq and Afghanistan, the US government employed more than 260,000 contractors, which at times exceeded the total number of US military personnel deployed in those two countries. ${ }^{9}$ Such contractors have performed a myriad of roles, from constructing military bases and refugee camps to cutting soldiers' hair, serving meals in mess halls, maintaining weapons on the battlefield, interrogating detainees, and guarding diplomats and military facilities. ${ }^{10}$ Scholars and policy-makers have confronted the legal implications of this shift, and many have called for increasing oversight. ${ }^{11}$

Yet few, if any, studies have addressed the potentially incendiary mix of legal challenges arising from the combined use of drones and automated weapons, on the one hand, and private contractors, on the other. These trends have occurred side-byside and even reinforce each other, because drones and automated weapons themselves often depend on contractors to function. Each twenty-four-hour combat air patrol of the US armed Predator and Reaper drones, for example, requires at least 350 people, many of whom are contractors. Contractors often invent and produce autonomous systems, and contractors may also be responsible for maintaining and operating these systems on the battlefield.

This chapter charts the rapid and intertwined growth of unmanned and increasingly autonomous weapons, on the one hand, and private military and security contractors, on the other. And it grapples with the particular challenges this combination of forces creates under both domestic and international law. The first part describes the increased use of drones and more fully autonomous weapons as well as

\footnotetext{
"On the Moral Equality of Combatants" (2006) 14(4) Journal of Political Philosophy 377-496 (same).

7 Memorandum for the Attorney General re: Applicability of Federal Criminal Laws and the Constitution to Contemplated Lethal Operations Against Shaykh Anwar al-Aulaqi (Washington, DC: Office of Legal Counsel, 2010), https://perma.cc/AKQ5-GBVQ; see also Daskal, "The Geography of the Battlefield."

8 See, e.g., D. Avant, The Market for Force: The Consequences of Privatizing Security (Cambridge: Cambridge University Press, 2005); L. Dickinson, Outsourcing War and Peace: Preserving Public Values in a World of Privatized Foreign Affairs (New Haven, CT: Yale University Press, 2011); S. McFate, The Modern Mercenary: The Rise of the Privatized Military Industry (Oxford: Oxford University Press, 2014); P. Singer, Corporate Warriors: The Rise of the Privatized Military Industry (Ithaca, NY: Cornell University Press, 2007).

9 Transforming Wartime Contracting: Controlling Costs, Reducing Risk - Final Report to Congress (Arlington, VA: Commission on Wartime Contracting, 2011).

1 Dickinson, Outsourcing War and Peace; see also discussion below.
}

10 Ibid. 
the growing role of contractors in developing and operating these systems. The next part discusses the destabilizing impact that this trend is having on one of the foundations of the US constitutional framework itself: the allocation of power between the president and Congress in deciding whether or not to use force overseas. By reducing the political cost of war, the rise of these weapons systems and the growing use of contractors have together emboldened the president to deploy force unilaterally. At the same time, these twin trends have made possible legal arguments that the use of force is itself not significant enough to warrant congressional involvement. Such arguments are premised upon the idea that if there are few US military casualties there is less likely to be a war for constitutional purposes, or hostilities within the meaning of the War Powers Resolution. This reality is made possible in part because the use of autonomous weapons and contractors radically reduces the official casualty count.

The final part charts the similarly disruptive impact these trends have had on accountability and oversight under IHL. Together, the use of autonomous weapons and privatization have fragmented decision-making over the use of force, rendering accountability for violations of IHL principles much more difficult to achieve. Accordingly, from the perspective of both domestic and international law, the rise of autonomous weaponry combined with the increased use of contractors raises significant challenges to the rule of law during armed conflict and the protection of human rights in noncombat contexts.

\section{THE RISE OF DRONES AND AUTONOMOUS WEAPONS, AND THE INCREASING ROLE OF MILITARY CONTRACTORS}

\section{A Drones}

Unmanned aerial vehicles (UAVs), popularly referred to as "drones," are now a seemingly permanent and pervasive fixture of the United States' strategy to combat terrorism. These remote-controlled flight technologies are probably best known for their ability to drop bombs on terrorism suspects without putting US troops in harm's way. Less discussed is their even bigger role in conducting surveillance. Such remote surveillance has radically reshaped and augmented military capabilities, both because UAVs can provide so-called enhanced situational awareness without endangering US troops on the ground and because they gather an enormous store of information that can then be used for multiple strategic purposes. ${ }^{12}$ Given these important benefits, it is not surprising that drone use has surged

12 See J. Levs, "CNN Explains: U.S. Drones," CNN, February 8, 2013, https://perma.cc/QUK5UH6M; J. Gertler, U.S. Unmanned Aerial Systems (CRS Report No. R42136) (Washington, DC: Congressional Research Service, 2012), https://perma.cc/HS6H-UU9A. 
dramatically in recent years. ${ }^{13}$ The 2016 fiscal budget included $\$ 2.9$ billion (US billion) for known costs in drone research, development, and procurement, and the Pentagon has at least 7,000 drones under its control. ${ }^{14}$ Drone technology has become "fundamental" to military operations, and demand for the technology far outstrips the actual supply. ${ }^{15}$

While the US overseas drone program has garnered significant public scrutiny, the integral role of contractors in developing and operating drones has attracted much less attention. It should be no surprise that leading defense firms develop and manufacture the broad range of drones that the United States uses, including the enormous high-flying RQ-4 Global Hawk (Northrup Grumman), with its powerful intelligence, surveillance, and reconnaissance capabilities; the deadly MQ-9 Reaper and MQ1 Predator (General Atomics), tactical strike and imaging drones that form the core of the US fleet unleashing bombs on terrorists; and tiny, handheld, battery-powered drones like the Dragon Eye (AeroVironment) and FQM Pointer (AeroVironment), which soldiers release from their backpacks to gather information.

But contractors also play a central role in the operation of drones, which for the larger models requires enormous teams of people. For example, each twenty-fourhour surveillance mission of the Global Hawk requires roughly 300-500 people. Each twenty-four-hour combat air patrol of the slightly smaller Predator and Reaper could require up to 350 people. Even the tiny handheld Dragon Eye and FQM Pointer depend on background teams of maintenance staff and intelligence analysts.

Contractors participate in almost every step of the complex array of tasks that make up a drone mission. Once the government purchases a drone, the manufacturer often provides continuing maintenance and logistical support services. ${ }^{16}$ For example, in addition to assembling drones and providing maintenance for them, contractors have also reportedly fueled them and loaded ammunition onto them at military bases overseas. ${ }^{17}$ Contractors also help operate drones, including, at times,

13 U.S. Unmanned Systems Integrated Roadmap (fiscal years 2009-2034) (Washington, DC: US Department of Defense, 2009), p. 2, https://perma.cc/T88M-BYMA; Statement of Commander Gerald Lloyd J. Austin III before the House Armed Services Committee, 114th Cong. (2015), p. 41, https://perma.cc/M856-L7VL; see also Bergen, Drone Wars, p. 12 (chart outlining the differences between the number of air strikes and drone strikes comparing 2002 through 2013).

14 "Understanding Drones," Friends Committee on National Legislation, https://perma.cc/gAV8VWTP (drawing numbers from the 2016 budget and military reports).

15 Statement of Commander Gerald Lloyd J. Austin III; C. Whitlock, "How crashing US drones are exposing secrets about US war operations," The Washington Post, March 25, 2015, https:// perma.cc/SP5F-S88P.

16 D. Cloud, "Civilian contractors playing key roles in U.S. drone operations," Los Angeles Times, December 29, 2011, https://perma.cc/6VSZ-P3 $\mathrm{M}_{3}$.

17 A. Sundby, "CIA Hired Blackwater to Arm Afghan Drones," CBS News, August 21, 2009, https://perma.cc/6PSU-GGQL; J. Risen and M. Mazzetti, "C.I.A. Said to Use Outsiders to Put Bombs on Drones," The New York Times, August 20, 2009, www.nytimes.com/2009/08/21/us/ 21intel.html; Cloud, "Civilian Contractors." 
steering them. ${ }^{18}$ The Air Force has stated that while contractors do not "pilot" drones during the targeting portion of their missions, contractors do assist with other aspects of flight, such as takeoff and landing. In addition, the ever-present demand for drone missions, particularly as the conflict against ISIS escalated in Iraq and Syria, has led to pilot shortages and a growing need for contractors.

Finally, contractors also collect and analyze the data that drones gather. ${ }^{19}$ In many cases, they review the live footage captured by drones. ${ }^{20}$ Indeed, contractors frequently become the subject matter experts and can more easily distinguish patterns on the ground than their military counterparts. ${ }^{21}$ Thus, while the Air Force has said that contractors do not make targeting decisions, contractor analysis of data can often shade into decision-making. For example, a 2013 Washington Post report suggested that a contractor who reviewed live footage from a drone essentially directed a Navy Seal to a particular target. ${ }^{22}$ A more recent report by the Bureau of Investigative Journalism indicates that contractors working for the Department of Defense not only analyze the data from drones, but also provide evaluative judgments that may affect targeting decisions. ${ }^{23}$

\section{B Autonomous Weapons}

The development of increasingly autonomous weapons systems is also reshaping modern warfare. Although there are multiple potential definitions of "autonomous," the International Committee for the Red Cross defines an autonomous weapon as one "that is able to function in a self-contained and independent manner although its employment may initially be deployed or directed by a human operator" and that can "independently verify or detect a particular type of target object and then fire or detonate." ${ }^{24}$ An autonomous weapon system can also "learn or adapt its functioning

18 K. D. Clanahan, "Drone-Sourcing? United States Air Force Unmanned Aircraft Systems, Inherently Governmental Functions, and the Role of Contractors" (2012) 22 Federal Circuit Bar Journal, https://perma.cc/C238-2JVA; A. Fielding-Smith et al., "Revealed: Private firms at heart of US drone warfare," The Guardian, February 12, 2015, https://perma.cc/XG4Q-XVKL; see also A. Fielding-Smith and C. Black, "Pentagon's 'Insatiable Demand' for Drone War Intelligence," The Bureau of Investigative Journalism, July 30, 2015, https://perma.cc/F95V6SZT (describing the many layers of a drone mission, including the number of people reviewing the instructions, relaying information, and operating the chain of command).

19 Cloud, "Civilian Contractors"; Fielding-Smith et al., "Revealed."

20 See Fielding-Smith et al., "Revealed"; A. Fielding-Smith and C. Black, "Civilians who are drone pilots' extra eyes," The Guardian, August 2, 2015.

${ }^{21}$ Fielding-Smith et al., "Revealed."

22 D. Priest, "NSA growth fueled by need to target terrorists," The Washington Post, July 21, 2013, https://perma.cc/4JYS-BJQ6.

23 Fielding-Smith and Black, "Pentagon's 'Insatiable Demand'."

24 "International Humanitarian Law and the Challenges of Contemporary Armed Conflicts," Report of the 31st International Conference of the Red Cross and Red Crescent (Geneva: International Committee of the Red Cross, 2011), p. 39, https://perma.cc/ML 3 F-RUZB. Other organizations have defined autonomous weapons differently. For example, The US 
in response to changing circumstances in the environment in which it is deployed." 25 Most drones would not qualify as autonomous weapons, because human operators control them remotely. Yet many weapons systems, including a few types of drones, can now function autonomously to some degree. While fully autonomous weapons may still be decades away, current systems deployed on land, at sea, and in the air can now operate with an extraordinary degree of independence from individualized human decision-making.

In practice, militaries have deployed these systems primarily for defensive purposes, and they have retained a degree of human involvement even when the systems could operate without human participation. More than thirty countries are using such systems to defend military vehicles and bases. ${ }^{26}$ They typically protect predetermined areas by detecting incoming munitions, such as mortars, rockets, or other projectiles, and then automatically responding by neutralizing these objects. Governments tend to deploy them in fixed, rather than mobile, positions in unpopulated and relatively simple and predictable environments, such as at sea or in remote areas, and they typically target weapons and objects rather than persons. In most cases, the reaction time required for engagement is so short that human interaction with the machines is minimal. Often, the human being is only given a brief opportunity to accept or reject the system's choice of action before it deploys, or to override a course of action that the machine will otherwise take automatically. ${ }^{27}$

Department of Defense (DoD) distinguishes between fully and semi-autonomous weapon systems based on the machine's ability to make an autonomous choice. It defines fully autonomous weapon system as a "weapon system that, once activated, can select and engage targets without further intervention by a human operator." See "DoD Directive on Autonomy in Weapon Systems," ICRAC, November 27, 2012, https://perma.cc/U46R-9WUS. Human Rights Watch, by contrast, focuses on human involvement, classifying autonomous weapons as either "human-in-the-loop weapons," "human-on-the-loop weapons," or "human-out-of-theloop weapons." Human-in-the-loop weapons are "robots that can select targets and deliver force only with a human command," while human-on-the-loop weapons are "robots that can select targets and deliver force under the oversight of a human operator who can override the robots' actions." Finally, human-out-of-the-loop weapons are "capable of selecting targets and delivering force without any human input or interaction.” B. Docherty, "Losing Humanity: The Case against Killer Robots," Human Rights Watch, November 19, 2012, p. 2, https://perma.cc/N77JEASX. The United Nations defines autonomous weapons as systems that "once activated, can select and engage targets without further intervention by a human operator." Report of the Special Rapporteur on Extrajudicial, Summary or Arbitrary Executions, Christof Heyns, U.N. Doc. A/HRC/23/47 (April 9, 2013).

25 Ibid., p. 39; see also "Autonomous weapons: States must address major humanitarian, ethical challenges," International Committee of the Red Cross, February 9, 2013, https://perma.cc/ $\mathrm{PD}_{33}-\mathrm{Z}_{5} \mathrm{M}_{7}$.

26 P. Scharre and M. Horwoit, "An Introduction to Autonomy in Weapon Systems," Center for a New American Security (February 13, 2015), https://perma.cc/3BDX-SGW6.

27 These countries are: Australia, Bahrain, Belgium, Canada, Chile, China, Egypt, France, Germany, Greece, India, Israel, Japan, Kuwait, the Netherlands, New Zealand, Norway, Pakistan, Poland, Portugal, Qatar, Russia, Saudi Arabia, South Africa, South Korea, Spain, Taiwan, the United Arab Emirates, the United Kingdom, and the United States. Ibid. 
A semi-autonomous offensive system, which mostly consists of projectiles, tends to require a human operator to launch, ${ }^{28}$ but then autonomously guides the weapon to a preselected target, either by relying on passive sensors that respond to signals from the environment or by using active sensors that send out signals and look for a signal in return. ${ }^{29}$ Known as guided munitions, these projectiles can be divided into two categories: "go-onto-target" projectiles, designed to hit a particular target, and "goonto-location" projectiles, designed to hit a particular geographic location. ${ }^{30}$ In some cases, humans can "control, abort, or retarget" such weapons in flight, but other times the projectiles cannot be adjusted once launched. ${ }^{31}$

As with drones, private military contractors have been major players in inventing and producing these autonomous systems. ${ }^{32}$ But perhaps even more significant is the potential role contractors play in testing, maintaining, and operating them. The military typically hires private contractors to test autonomous weapons systems in order to determine whether they will be effective and whether any changes need to be made before deployment. Sometimes contactors actually test their products in the field. For example, integrated teams of Northrop Grumman contractors and Navy personnel have tested the unmanned $\mathrm{X}_{-47} \mathrm{~B}$ to prove that it is capable of operating in tandem with manned aircraft. ${ }^{33}$ Based on such tests, private companies often receive contracts to upgrade autonomous weapons systems. ${ }^{34}$ Finally, in some cases private contractors provide maintenance on autonomous weapons being used in the field in active deployment situations. For example, the US Army contracted with Northrop Grumman to install and maintain the C-RAM interceptor system at forward operating bases during Operation Enduring Freedom and the ongoing US mission in Iraq. ${ }^{35}$ And Raytheon is currently contracted to provide ongoing technical and support services to the US Army on this system. ${ }^{36}$

28 Scharre and Horwoit, "An Introduction to Autonomy in Weapon Systems," pp. 8-10.

29 Ibid.

30 Ibid.

31 Ibid.

$3^{2}$ See, e.g., P. Jones, “Aegis Combat System's Newest Baseline Demonstrates Over the Horizon Capability in Series of Three Tests," Lockheed Martin, July 8, 2014, https://perma.cc/APE6-

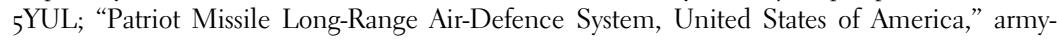
technology.com, https://perma.cc/3JUS-FZE7; “Terminal High Altitude Area Defense, United States of America," army-technology.com, https://perma.cc/T88S-Y4NG; "Taranis is an unmanned combat aircraft system advanced technology demonstrator programme," BAE Systems, https://perma.cc/K3/8-46AJ.

33 S. J. Freedberg Jr., "X-47B Drone \& Manned F-18 Take Off \& Land Together in Historic Test," Breaking Defense, August 17, 2014, https://perma.cc/5JZE-9NHR.

34 For example, Raytheon received a \$115.5 million contract in 2014 to "remanufacture, overhaul and provide upgrades" to the MK ${ }_{15}$ Phalanx system. "Raytheon awarded \$115.5 million Phalanx upgrade contract,” Raytheon, June 11, 2014, https://perma.cc/DA5P-U8MS.

35 “Northrop wins US Army's C-RAM contract," army-technology.com, January 31, 2012, https:// perma.cc/WH37-44ZM.

36 "Raytheon receives \$109 million contract for Patriot Air and Missile Defense System: US and international Patriot partners strengthen defense against evolving threats," Raytheon, September 10, 2014, https://perma.cc/B462-8D4Q. 
Contractors have even been hired to provide support to the autonomous systems being used in the field. Lockheed Martin has served as the AEGIS combat system engineering agent for the US Navy for the last forty years. ${ }^{37}$ Currently, Northrop Grumman is fulfilling a $\$ 122$ million contract with the US Army to "provide systems engineering, production, deployment and logistics support services for the C-RAM systems." ${ }^{8} 8$ Similarly, the foreign firm Rheinmetall Air Defence has received a contract for $€_{20}$ million to provide documentation and training services for the Mantis, a short-range air defense protection system developed to protect the German Army in Afghanistan. ${ }^{39}$

\section{THE UNITED STATES SEPARATION OF POWERS FRAMEWORK}

This distinctive mix of autonomous devices and contractors upends traditional frameworks, both domestic and international, for regulating the conduct of war. This part examines how the rise of unmanned systems affects the implementation of the US constitutional and statutory regime governing the decision to use force abroad. The next part turns to the impact on the international humanitarian law regime.

The US Constitution explicitly and purposefully divides responsibility over the use of force abroad between the Congress and the president. Under the Constitution, Congress declares war ${ }^{40}$ and holds the purse strings, ${ }^{41}$ while the president is commander-in-chief of the armed forces. ${ }^{42}$ Debates about the scope of the president's power in relation to Congress date back centuries ${ }^{43}$ and have grown more fraught in the last fifty years as formal declarations of war have largely become a historical relic. ${ }^{44}$ Some scholars and government lawyers have asserted broad theories of the president's inherent power to use force unilaterally, ${ }^{45}$ while others have taken a more restrained approach, articulating a view that shared responsibility

37 "Aegis Combat System's Newest Baseline."

38 "Northrop Wins US Army's C-RAM Contract."

39 "NBS MANTIS Air Defence Protection System, Germany" army-technology.com, https:// perma.cc/Y49B-FHEC.

$4^{\circ}$ US Const., art. I, $\int 8$, cl. 11.

$4^{1}$ US Const., art. I, $\int 8$, cls. 12-13.

$4^{2}$ US Const., art. I, $\mathbb{2} 2$.

43 Compare the Prize Cases, 67 U.S. (2 Black) 635 (1863) (upholding the constitutionality of President Lincoln's unilateral decision to impose naval blockade during the Civil War, when Congress was not in session) with Little v. Barreme, 6 U.S. (2 Cranch) 170 (1804) (concluding that a US naval captain's seizure of a ship sailing from a French port during the naval war with France was unjustified because Congress had only authorized seizures of ships sailing to French ports).

44 The United States has not formally declared war since World War II. See Joint Resolution Declaring That a State of War Exists Between the Government of Rumania and the Government and the People of the United States and Making Provisions to Prosecute the Same, ch. 325, 56 Stat. 307 (June 5, 1942) (last declaration of war by the United States).

45 See, e.g., L. Meeker, "The Legality of United States Participation in the Defense of Viet-Nam" (1966) 54 Department of State Bulletin 474, reprinted in (1966) 75(7) Yale Law Journal 
between the president and Congress should continue. ${ }^{6}{ }^{6}$ After the Vietnam War, Congress tried to protect its position by enacting the War Powers Resolution, which requires the president to halt "hostilities" if Congress has not approved them within sixty days. ${ }^{47}$ Since then, while Congress has, at times, spoken loudly to authorize the use of force - as it did in 2001 to allow a muscular response to Al Qaeda and the Taliban $^{48}$ and in 2003 to authorize the war in Iraq ${ }^{49}-$ at other times, Congress's voice has been muted at best. Years into the US operations against the Islamic State in Iraq and Syria (ISIS), no new authorization of force was forthcoming from Congress.

In the face of congressional silence, the rise of unmanned systems, combined with the growing use of contractors, has enabled the president to claim greater scope for unilateral action. New technology has not merely emboldened the president politically, but has actually made possible new legal arguments to justify an expanded conception of the president's role in relation to Congress. In order to see the development of these new legal arguments, this part focuses on three examples where the president used force overseas without receiving specific congressional approval: Kosovo in 1999, Libya in 2011, and the campaign against ISIS in Iraq and Syria beginning in 2014. In each case, we can see that the growing role of unmanned systems and contractors has opened space for legal arguments expanding the power of the executive branch.

\section{A Kosovo}

To understand the power shift that new technologies and the use of contractors have produced, and the impact of these trends on legal arguments about the use of force, it is useful to go back to 1999, when US President Bill Clinton sought to halt the ethnic cleansing campaign of the Yugoslav dictator Slobodan Milosevic in Kosovo. With the humiliating deaths of US troops in Mogadishu, Somalia, in 1993 still fresh in Americans' minds, President Clinton aimed to intervene in a way that would minimize the risk of US casualties by relying primarily on an air

1085-108; J. Yoo, "The Continuation of Politics by Other Means: The Original Understanding of War Powers" (1996) 84(2) California Law Review 167-305.

$4^{6}$ See, e.g., H. Koh, The National Security Constitution (New Haven, CT: Yale University Press, 1990); D. Barron and M. Lederman, "The Commander in Chief at the Lowest Ebb - Framing the Problem, Doctrine, and Original Understanding" (2008) 121(3) Harvard Law Review 689-804.

47 War Powers Resolution, 50 U.S.C. $\iint 1541-48$ (1973); see P. Holt, The War Powers Resolution (Washington, DC: American Enterprise Institute for Public Policy Research, 1978).

${ }^{4}$ Joint Resolution to use the United States Armed Forces against those responsible for the recent attacks launched against the United States, Pub. L. No. 107-40, \$2(a), 115 Stat. 224 (2001).

49 Authorization for Use of Military Force Against Iraq Resolution of 2002, Pub. L. No. 107-243, 116 Stat. 1498 (2002). 
campaign carried out jointly with the North Atlantic Treaty Organization (NATO). $5^{\circ}$ This strategy endeavored to stop the killing without spilling American blood.

The military campaign was swift. President Clinton ordered US air strikes to begin in the province of Serbia on March 24, 1999, without explicit congressional approval. ${ }^{51}$ The effort, conducted along with other NATO countries, lasted seventyeight days and consisted entirely of an air campaign. ${ }^{2}$ Of 37,000 sorties, the United States flew 23,208 (62 percent).53 When President Milosevic agreed to withdraw Yugoslav forces from the region and allow the presence of a United Nations peacekeeping force on June 10, 1999, NATO suspended the bombing. ${ }^{54}$ There were no combat casualties, a point the president highlighted at the end of the campaign. ${ }^{55}$ Civilian casualties among the Yugoslav population, however, were in the range of $480-530 . .^{6}$

Drones were also a part of the story. The US military had harnessed unmanned aircraft for surveillance as far back as the Vietnam War, when "Lightning Bugs" gathered information on the North Vietnamese. By 1999, drones had evolved sufficiently to give the military improved situational awareness and enable better targeting. During Operation Allied Force in Kosovo, the unmanned vehicles operated as "remote-controlled intelligence and surveillance platforms." military employed three tactical systems: the Air Force Predator, the Army Hunter, and the Navy Pioneer. ${ }^{58}$ The Defense Department after-action report to Congress highlighted the significance of the new technology, emphasizing that the drones were used at "unprecedented levels" and "played an important role in our overall success." 59 Specifically, the report noted, drones "enabled commanders to see the situation on the ground without putting aircrews at risk and provided continuous

$5^{\circ}$ See President William Jefferson Clinton, "Statement on Kosovo," March 24, 1999; President William Jefferson Clinton, "Letter to Congressional Leaders Reporting on Airstrikes Against Serbian Targets in the Federal Republic of Yugoslavia (Serbia and Montenegro)" (1999) 35 Weekly Compilation of Presidential Documents 527, https://perma.cc/ZQ2Q-U8SK; see also "The Kosovo Air Campaign: Operation Allied Force," North Atlantic Treaty Organization, November 11, 2014, https:/perma.cc/ESU5-4C27.

$5^{1}$ Clinton, "Letter to Congressional Leaders."

52 S. Bowman, Kosovo and Macedonia: U.S. and Allied Response (CRS Issue Brief) (Washington, DC: Congressional Research Service, 2003), https://perma.cc/VDP5-M25F.

53 Ibid.

54 Ibid.

55 President William Jefferson Clinton, Address on the Kosovo Agreement, June 10, 1999, https:// perma.cc/F99V-DCMJ.

${ }^{6}$ Human Rights Watch, The Crisis in Kosovo (2000), https://perma.cc/MBX $4-7 \mathrm{M}_{3} \mathrm{P}$.

57 Report to Congress: Kosovo Operation Allied Force After-Action Report (Department of Defense, 2000), https://perma.cc/NF2L-NH99.

$5^{8}$ Ibid.

59 Ibid.; see also E. Becker, "Military Leaders Tell Congress of NATO Errors in Kosovo," The New York Times, October 15, 1999. 
coverage of important areas." 60 Their ability to convey live video feeds for "real-time targeting" was key. At this point, the drones did not conduct strikes, but they could fly lower than military aircraft, scout out targets, and transmit information in real time to minimize civilian casualties and make the air strategy more effective.

Contractors also formed a crucial element of the military strategy. During the air campaign, contractors provided intelligence support, served as linguists, transported fuel from barges on the Adriatic to locations inland, and built three refugee camps for displaced Kosovars. ${ }^{61}$ After the primary air campaign ended, military contractors poured into the region, augmenting the US contingent of peacekeepers. The contractors performed an unprecedented variety of roles, including logistics, construction, training, and policing. ${ }^{62}$ Significantly, their presence allowed the US military to contribute a much smaller number of troops $(7,000)$ than might otherwise have been needed. ${ }^{6}{ }_{3}$ Overall, in the Balkans, the number of contractors far exceeded the number of troops, at a ratio of approximately $1.5^{-1} .{ }^{6}$ It would be fair to say that the combined power of drones and contractors delivered a one-two punch that enabled the US military to reduce its footprint and the risk of military casualties.

This strategy of waging war from a safe distance, made possible in part by new technologies and contractors, gave the president more political leeway to act without clear approval from Congress. With regard to Kosovo, Congress debated the conflict extensively but neither explicitly supported nor opposed it, because those in favor of military action never mustered enough votes to pass a resolution permitting the use of force. The US House of Representatives narrowly defeated a concurrent resolution that would have authorized the air strikes $(213-213)^{65}$ and voted down a declaration of war by an overwhelming majority $(427-2) .{ }^{66}$ At the same time, those who opposed the intervention also could not garner enough support to pass resolutions condemning the strikes. Indeed, a concurrent resolution introduced in the House by Rep. Tom Campbell (R-California) directing the president to remove armed forces from Serbia within thirty days lost by a large majority. ${ }^{67}$ The House did

60 Department of Defense, Report to Congress (describing statements of Pentagon officials that drones provided "indispensable" assistance in US air campaign).

${ }^{61}$ Ibid., p. 116

${ }^{62}$ M. Schwartz and J. Church, Department of Defense's Use of Contractors to Support Military Operations: Background, Analysis and Issues for Congress (Congressional Research Service, 2013), https://perma.cc/JUT9-6JY8.

63 Department of Defense, Report to Congress.

${ }^{6}$ See R. Fontaine and J. Nagl, "Contractors in American Conflicts: Adapting to a New Reality," Center for a New American Security, December 16, 2009, https://perma.cc/N4RP-HVSH; see also "Contingency Contracting throughout U.S. History," Office of Defense Procurement and Acquisition Policy, https://perma.cc/W588-NBWB.

${ }_{5}$ H.J. Res. 44, 106th Cong. (1999), 145 Cong. Rec. H2441 (daily ed. April 28, 1999); ibid., H245152 (recording vote).

66145 Cong. Rec. $\mathrm{H}_{2474}$ (daily ed. April 28, 1999); ibid. at H2440-41 (recording vote).

67 H. Con. Res. 82, 106th Cong. (1999), 145 Cong. Rec. H2414 (daily ed. April 28, 1999) (reprinting H. Con. Res. 82); ibid. at $\mathrm{H}_{24} 26-27$ (recording vote). 
vote $(249-180)$ to block funding for ground troops, ${ }^{68}$ but Congress subsequently passed an emergency supplemental appropriations bill allocating \$12.9 billion (US billion) for the campaign. ${ }^{69}$

While Congress remained split, the aerial military strategy emboldened Clinton administration lawyers to justify the unilateral use of force as a legal matter. The Department of Justice Office of Legal Counsel (OLC) did not explicitly explain the constitutional basis of the president's authority to conduct the Kosovo campaign in the absence of Congress's authorization. Instead, an OLC memo articulated in general terms the purpose of the military action: "to demonstrate the seriousness of NATO's purpose so that the Serbian leaders understand the imperative of reversing course; to deter an even bloodier offensive against innocent civilians in Kosovo; and, if necessary, to seriously damage the Serbian military's capacity to harm the people of Kosovo." ${ }^{\circ}$ However, the memo did contend that the president had not run afoul of the sixty-day clock imposed by Section 5(b) of the War Powers Resolution. Although that provision stops the president from using force in "hostilities" without congressional approval, OLC argued that Congress had in fact authorized the use of force by funding the campaign, even though Section 8(a) of the War Powers Resolution purports to disallow such an approach.

Despite the ambiguity at the time, when OLC lawyers sought to explain the legal basis of President Barack Obama's use of force in Libya in 2011 a decade and a half later, they drew a comparison to Kosovo. Specifically, they suggested that the low risk of US casualties in the Kosovo campaign justified, in part, exempting the president from needing to seek congressional approval either as a constitutional matter or within the framework of the War Powers Resolution. The memo reasoned that the Kosovo campaign "avoided the difficulties of withdrawal and risks of escalation that may attend commitment of ground forces - two factors that this Office has identified as 'arguably' indicating 'a greater need for approval [from Congress] at the outset'."71 The memo also emphasized that, "as in prior operations conducted without a declaration of war or other specific authorizing legislation, the anticipated operations here served a 'limited mission'." Thus, OLC implied that Clinton never needed to get Congress's blessing, in part because of the minimal risk

68 H.R. 1569, 106th Cong. (1999), 145 Cong. Rec. H2400 (reprinting measure); ibid. at H2413-14 (recording votes).

69 H.R. 1664, 106th Cong. (1999), 145 Cong. Rec. H2634 (daily ed. May 4, 1999); see also A. Taylor, "Paying for the Kosovo Air War: How Much Is Too Much?," CQ Weekly, May 1, 1999, p. 1014. Following a floor debate on May 6, the House passed H.R. 1664 the same day by a vote of 311-105. 145 Cong. Rec. $\mathrm{H}_{2} 895$ (daily ed. May 6, 1999).

70 "Authorization for Continuing Hostilities in Kosovo" (2000) 24 Opinions of the Office of Legal Counsel 327, https://perma.cc/C52J-TSA7; see also "Proposed Deployment of United States Armed Forces into Bosnia," 19 Opinions of the Office of Legal Counsel 327 at 333, https:// perma.cc/9V49-4FEE.

71 "Authority to Use Military Force in Libya," 35 Opinions of the Office of Legal Counsel 1 at 13, https://perma.cc/9A2C-56XS. 
of casualties. Of course, the casualty count was so low largely because harm to drones and contractors is not tallied in the official casualty figures.

\section{B Libya}

A decade after the Kosovo intervention, another US president ordered a military campaign to halt the atrocities of another dictator without first seeking congressional approval. When Libyan President Muammar Qadhafi attacked civilians protesting his iron-fisted rule, and continued to do so in flagrant defiance of UN Security Council condemnation, ${ }^{72}$ President Obama joined a coalition of nations to initiate an air campaign to prevent further atrocities. In contrast to Kosovo, the Security Council had approved the multilateral intervention in Libya, imposing a no-fly zone and authorizing the use of force to protect civilians. ${ }^{73}$ As Qadhafi's forces were preparing to retake the city of Benghazi, the dictator pledged that his troops would show "no mercy and no pity" against protesters and that "[w]e will come house by house, room by room."74 Qadhafi, President Obama later noted, "compared [his people] to rats, and threatened to go door to door to inflict punishment... We knew that if we ... waited one more day, Benghazi, a city nearly the size of Charlotte, could suffer a massacre that would have reverberated across the region and stained the conscience of the world." 75

The US military intervention, dubbed Operation Odyssey Dawn, commenced on March 19, 2011. ${ }^{76}$ The same day, France and the United Kingdom, which had played leading roles in advocating for military action and had cosponsored the Security Council resolutions, commenced Operation Harmattan and Operation Ellamy, respectively, in coordination with the United States. ${ }^{77}$ US and coalition

${ }^{72}$ See, e.g., Security Council Res. 1970, U.N. Doc. S/RES/1970 (February 26, 2011), https://perma .cc/QARg-6VLR ("condemning the violence and use of force against civilians" and "deploring the gross and systematic violation of human rights" in the country); "In Swift, Decisive Action, Security Council Imposes Tough Measures on Libyan Regime, Adopting Resolution 1970 in Wake of Crackdown on Protesters," UN Security Council Press Release SC/10187/Rev. 1 (February 26, 2011), https://perma.cc/BKQ7-99CH.

73 See Security Council Res. 1973, U.N. Doc. S/RES/1973 (March 17, 2011), https://perma.cc/ 65UX-XLFC; "Security Council Approves 'No-Fly Zone' Over Libya, Authorizing 'All Necessary Measures' to Protect Civilians, by Vote of 10 in Favour with 5 Abstentions," UN Security Council press release SC/10200 (March 17, 2011), https://perma.cc/63RT-SJAX.

74 See D. Bilefsky and M. Landler, "Military Action against Qaddafi Is Backed by U.N.", The New York Times, March 18, 2011, p. A1.

75 The White House, "Remarks by the President in Address to the Nation on Libya," Press Release, March 28, 2011, https://perma.cc/2UU6-F6M6.

${ }^{6}$ J. Gertler, Operation Odyssey Dawn (Libya): Background and Issues for Congress (CRS Report No. R41725) (Washington, DC: Congressional Research Service, 2011), https://perma.cc/74WT$\mathrm{WJN}_{4}$.

77 Ibid. 
forces quickly established command of the air over Libya's major cities, destroying portions of the Libyan air defense network and attacking pro-Qadhafi forces deemed to pose a threat to civilian populations. ${ }^{7}$

At the time, President Obama emphasized that US military involvement in the operation would be limited. In his report to Congress on March 21, 2011, he explained that the use of military force in Libya served important US interests by preventing instability in the Middle East and preserving the credibility and effectiveness of the United Nations Security Council. ${ }^{79} \mathrm{He}$ also stated that the goal of US operations was to "set the stage" for further action by coalition partners. ${ }^{80}$ The president pledged that no US ground forces would be deployed, except possibly for search-and-rescue missions, and he asserted that the risk of substantial casualties for US forces would be low. ${ }^{81}$

Establishment of the no-fly zone over Libya proceeded relatively smoothly. One US aircraft was lost due to mechanical malfunction, but the crew was rescued. Estimates of the cost of the initial operation ranged between $\$ 400$ million and $\$ 1$ billion. NATO assumed control of military operations on March $30,2011,{ }^{82}$ and international military operations concluded later that year, on October 31, after the death of Qadhafi, when the Security Council ended the mandate for military action. ${ }^{83}$

Drones assumed an even larger role in Libya than they had during the Kosovo campaign. The technology of unmanned systems had evolved considerably. Drones now enhanced the Air Force's capability to better gather information for targeting because of their greater ability to fly low for extended periods, hover in densely populated areas, and transmit high-quality information in real time. ${ }^{84}$ This capacity increased the precision of conventional air power and helped reduce civilian casualties. Even more significantly, in addition to providing intelligence, drones could now themselves also drop bombs. The United States announced that it was sending its first armed Predator drones to the region in April 2011. ${ }^{85}$ During the roughly seven-month air campaign, US unmanned systems launched 145 of the strikes on Libya, almost half of the overall total of US strikes, while also doing most

$7^{8}$ Ibid.

79 President Barack Obama, Letter from the President regarding the commencement of operations in Libya, March 21, 2011, https://perma.cc/2HAL-P93Q.

so Ibid.

81 Ibid.; see also "Authority to Use Military Force in Libya."

${ }^{82}$ Gertler, Operation Odyssey Dawn.

83 "Security Council votes to end Libya operations," BBC News, October 27, 2011, https://perma .cc/7WZZ-SCHX.

84 See C. Pellerin, "Gates: Obama OKs Predator Strikes in Libya," Department of Defense News, April 21, 2011, https://perma.cc/56SW-YTJ9; see generally J. Walsh, The Effectiveness of Drone Strikes in Counterinsurgency and Counterterrorism Campaigns (Carlisle, PA: Strategic Studies Institute and US Army War College Press, 2013).

85 See Pellerin, "Gates: Obama OKs Strikes in Libya." 
of the spotting that enabled the manned strikes. ${ }^{86}$ Moreover, even after NATO announced that the conflict was over in October 2011, the drones did not go home, but rather continued to fly combat air patrols, primarily for surveillance. ${ }^{87}$

As in Kosovo, contractors also played a key role after the international air campaign ended. Because the new Libyan government expressed concerns about an extensive contractor presence, however, the contractor footprint was smaller and quieter. ${ }^{88}$ The US State Department did not contract with well-known security firms such as Blackwater, a company that had guarded US diplomats in Iraq but earned a poor reputation after multiple abuse-of-force incidents, such as the notorious September 2007 killing of civilians in Baghdad's Nisoor Square. Nevertheless, the US Embassy in Libya did employ contractors from lesser-known firms, some of which hired local nationals as employees. ${ }^{89}$ The CIA also used contractors in Libya. ${ }^{90}$ Indeed, in a brutal attack on September 11, 2012, militants killed not only the US ambassador, but also two American CIA contractors, Tyrone Woods and Glen Doherty. ${ }^{91}$ Thus, while the contractor role in Libya may have been more muted, the combination of drones and contractors again enabled the military to shrink its visible image, just as it had in Kosovo.

This seemingly smaller footprint both emboldened the president politically to take action without congressional approval and lent credence to legal arguments that he was neither constitutionally nor statutorily required to obtain such approval. As in the Kosovo context, Congress did not authorize the military action, although debate within the legislature resulted in a mix of actions on several resolutions pointing in multiple directions. In the House of Representatives, two resolutions came to the floor on June 3. The first, introduced by Rep. Dennis Kucinich (D-Ohio) with Republican cosponsors, directed the removal of US armed forces from Libya within fifteen days, but it failed $148-265$. The second, introduced by House Speaker John Boehner (R-Ohio), succeeded by a vote of $268-145$. It noted

86 See S. Ackerman, “Libya: The Real U.S. Drone War," Wired, October 20, 2011, https://perma .cc/24XG-JYRB; C. Woods and A. Ross, "Revealed: US and Britain Launched 1,200 Drone Strikes in Recent Wars," The British Bureau of Investigative Journalism, December 4, 2012, https://perma.cc/T787-QL6U.

${ }^{8} 7$ See S. Ackerman, "U.S. Drones Never Left Libya; Will Hunt Benghazi Thugs," Wired, September 12, 2012, https://perma.cc/XR56-LG9K.

88 J. Risen, "After Benghazi Attack, Private Security Hovers as an Issue," The New York Times, October 12, 2012, www.nytimes.com/2012/10/13/world/africa/private-security-hovers-as-issueafter-embassy-attack-in-benghazi-libya.html?_r=1; see also A. Mehra, "Time to Put Security Contractors Under the Gun," Huffington Post, February 28, 2013, https://perma.cc/K7HNF8ER.

89 Ibid.

$9^{\circ}$ Associated Press, "New Benghazi Investigation Finds No Fault in Response," The New York Times, November 21, 2014, www.nytimes.com/2014/11/22/us/new-benghazi-investigation-findsno-fault-in-response.html.

${ }^{91}$ Ibid.; see also D. Kirkpatrick, "A Deadly Mix in Benghazi," The New York Times, December 28, 2013, www.nytimes.com/projects/2013/benghazi/\#/?chapt=o. 
that President Obama had "failed to provide Congress with a compelling rationale" for military activities in Libya and directed him to describe in detail within fourteen days US interests and objectives in Libya, as well as the reason why he did not seek authorization from Congress to use military force. Although not legally bound by the resolution, the president did submit a report within the requested time frame. On June 24, the House voted down (123-295) a resolution that would have authorized the military action, and rejected by a smaller margin (180-230) a measure that would have provided limited funding for the war. A Senate resolution put forward by Senator John Kerry (D-Massachusetts) and Senator John McCain (R-Arizona) on June 24 would have authorized the use of force (while prohibiting boots on the ground) and agreed with the president that the military intervention did not require congressional authorization under the Constitution or the War Powers Resolution. ${ }^{92}$ That resolution was withdrawn without a vote..$^{93}$

Meanwhile, the president proceeded with the operation, while his lawyers made the case that, as a legal matter, "under these circumstances, the President had constitutional authority, as Commander-in-Chief and Chief Executive and pursuant to his foreign affairs powers, to direct such limited military operations abroad, even without prior specific congressional approval." 94 More specifically, the OLC memo justified the use of force by arguing that the multilateral nature of the oprations and the reduced risk of casualties - made possible by drones and contractors - exempted the operation from any constitutional requirement that Congress declare war or explicitly authorize the use of force. The memo reasoned that a particular use of force is a war "for constitutional purposes" only if there are "prolonged and substantial military engagements, typically involving exposure of U.S. military personnel to significant risk over a substantial period." In contrast, the military action in Libya, the memo argued, was "limited in scope and duration." Again, the so-called limited scope was made possible by the expanded role of drones and contractors substituting for military personnel.

In addition to the constitutional arguments in the OLC memo, other administration lawyers (over OLC's objections) also contended that the Libya campaign did not even fall within the War Powers Resolution's sixty-day limit on engaging in "hostilities" absent congressional authorization. Crucial to their reasoning was the fact that manned planes had moved quickly into a mere supporting role, even though "unmanned forces" continued to carry out strikes up to the very day Qaddafi

$9^{2}$ A joint resolution authorizing the limited use of the United States Armed Forces in support of the NATO mission in Libya, S.J. Res. 20, June 21, 2011, https://perma.cc/5JZ5-TFJH. The resolution also would have prohibited deployment of security contractors. See Kirkpatrick, "A Deadly Mix in Benghazi."

93 See generally L. Fisher, "Senate Should Protect War Powers on Libya," Roll Call, June 28, 2011, https://perma.cc/6Q $72-69$ QU.

94 "Authority to Use Military Force in Libya," 
was killed. In other words, so the argument went, because US blood would not be at risk, it didn't count as warfare. ${ }^{95}$

\section{ISIS}

The military engagements in the Balkans and Libya set the stage for the campaign against ISIS in Iraq and Syria. ISIS is a transnational Sunni Islamist insurgent and terrorist group that expanded its control over areas of northwestern Iraq and northeastern Syria beginning in 2013, threatening the security of both countries and drawing increased attention from the international community. ${ }^{96}$ The group emerged against the backdrop of the brutal Syrian regime of President Bashir al-Assad, the disintegration of the country into civil war, and the sectarian strife within Iraq, where many segments of the Sunni population felt that they had not received adequate representation within the predominantly Shiite government. ${ }^{97}$

In the face of ISIS military gains in Iraq and Syria, the United States launched an air campaign against the group beginning in August 2014. Drone strikes in this campaign have been significant. During the ten-month period from August 2014 to June 2015, for example, US and coalition forces used combat aircraft, armed unmanned aerial vehicles, and sea-launched cruise missiles to conduct more than 3,700 strikes in Iraq and Syria. ${ }^{8}$ Further strikes have continued since that time.

The stated objective of these US strikes has evolved somewhat as circumstances have changed. Initially, the goal was to halt the advance of ISIS forces and reduce threats to American personnel and religious minorities in northern Iraq; subsequently, the objective included support for Iraqi military and Kurdish forces, with the aim of weakening the ability of ISIS to support its Iraq operation from within Syria. Other US strikes have targeted individuals belonging to the "Khorasan Group," an Al Qaeda affiliate whose leadership is based in Pakistan.99

Drones have played an even more significant part in the campaign against ISIS than they did in Libya. US Central Command has reported that drone strikes constituted about 15 percent of the overall number of strikes, ${ }^{100}$ and drone surveillance capabilities enabled so-called eyes on the ground, particularly in

95 For a discussion of these arguments, see C. Savage, Power Wars: Inside Obama's Post-g/11

Presidency (New York: Little, Brown, and Company 2015), pp. 635-654.

${ }^{6}$ C. Blanchard and C. Humud, The "Islamic State" Crisis and U.S. Policy (CRS Report No. $\mathrm{R}_{43} 612$ ) (Washington, DC: Congressional Research Service, 2015), https://perma.cc/CV2EPV9A.

97 Ibid.

$9^{8}$ Ibid.

99 Ibid.

${ }^{100}$ E. Schmitt, "Obstacles Limit Targets and Pace of Strikes against ISIS," The New York Times, November 9, 2014, www.nytimes.com/2014/11/10/world/middleeast/trouble-pinning-down-isistargets-impedes-airstrikes.html?mcubz=2. 
denser urban areas. Indeed, demand for drones was so high and drone pilots became so overworked that in 2015 the US Air Force announced a crisis of drone "pilot fatigue." 101

Contractor involvement has also been significant. While the number of military and security contractors has not swelled to levels witnessed during the previous phase of the conflicts in Iraq and Afghanistan, ${ }^{102}$ US Central Command reported in July 2015 that the Department of Defense was employing 41,900 military contractors in the area within Central Command's responsibility. ${ }^{103}$ And this figure did not even include the State Department contractors who were providing services such as security to US diplomats, as the State Department does not release data on contractor numbers. ${ }^{104}$

Contractors continue to provide extensive support to the drone operations themselves - performing maintenance on unmanned vehicles, loading bombs into them, analyzing the intelligence feeds they provide, piloting unarmed drones, and in some cases steering the takeoff and landing of armed drones. ${ }^{105}$ And although contractors have not officially selected targets, some of their activities, such as intelligence analysis, have, at times, contributed to target selection. Certainly contractors were (and are) performing virtually the entire array of tasks associated with the operation of unmanned vehicles.

As in the Kosovo and Libya conflicts, the combined force of drones and contractors enabled the Obama administration to maintain the appearance of a small military footprint with minimal risk of harm to US troops. Indeed, President Obama repeatedly stressed that he would not deploy ground combat units to fight ISIS, maintaining that US troops could not fix the underlying political problems that ultimately caused the crisis. ${ }^{106}$ While the president left the door open for the possibility of small special forces rescue missions and operations to target the ISIS leadership, he ruled out "enduring offensive ground combat operations."107

The Obama administration's legal justification under domestic law for the military intervention rested on the preexisting Authorization to Use Force against $\mathrm{Al}$

${ }^{101}$ C. Drew and D. Philipps, "As Stress Drives Off Drone Operators, Air Force Must Cut Flights," The New York Times, June 16, 2015, www.nytimes.com/2015/06/17/us/as-stress-drives-off-droneoperators-air-force-must-cut-flights.html?_r=1.

102 "Transforming Wartime Contracting."

${ }^{103}$ Contractor Support of U.S. Operations in the USCENTCOM Area of Responsibility (Department of Defense, 2016), https://perma.cc/FFE8-SXFZ.

${ }^{104}$ See J. Risen and M. Rosenberg, "Blackwater's Legacy Goes Beyond Public View," The New York Times, April 14, 2015, www.nytimes.com/2015/04/15/world/middleeast/blackwaters-legacygoes-beyond-public-view.html.

${ }^{105}$ See discussion below at text accompanying nn. 12-23.

${ }^{106}$ Blanchard and Humud, The "Islamic State" Crisis and U.S. Policy.

107 President Barack Obama, Letter to the Congress of the United States, February 11, 2015, https:// perma.cc/9SJN-K4X6; Draft Joint Resolution for Congress to Authorize the Limited Use of Force Against the Islamic State of Iraq and the Levant, February 11, 2015, https://perma.cc/ FMQ9-BJVR. 
Qaeda (and the Taliban) from 2001, ${ }^{108}$ as well as the Authorization to Use Force in Iraq. ${ }^{109}$ This legal theory, however, required the administration to draw a tenuous link between ISIS and Al Qaeda, two terrorist organizations that were literally fighting each other on the ground in Syria. ${ }^{110}$ The administration sought a new authorization to use force, but action on that authorization stalled. Instead, members of Congress seemed content to acquiesce in this legal pretzel logic in order to avoid another vote.

However, even without new authorization from Congress, the precedent now exists for executive branch lawyers to contend that operations against ISIS (or similar operations elsewhere) might not require congressional authorization. To be sure, the Obama administration lawyers who supplied the legal reasoning for the Libya intervention would, in all likelihood, not have carried their arguments that far. Nonetheless, the legal groundwork now exists for the claim that a low risk of troop casualties, made possible by the involvement of contractors and autonomous weapons, could form the basis of military involvement of such "limited nature, scope, and duration" that it would not be big enough to trigger the need for congressional authorization.

The implications of this argument are profoundly unsettling for the historical constitutional tradition of "mutual participation" between the president and Congress in waging war. ${ }^{111}$ To be sure, Congress's abdication of its role and the corresponding swelling scope of presidential authority is a continuing storyline from the Korean War to the present. ${ }^{112}$ Yet the force of new, increasingly automated military technologies, combined with growing military contracting, has arguably catapulted the phenomenon to another level. Not only have these new technologies and methods of warfare strengthened the executive's political hand to use force unilaterally while keeping US military casualties low, but the twin trends of autonomous weapons and privatization have opened the door to legal claims that the use of force is so limited that congressional assent is neither constitutionally nor statutorily necessary. In so doing, these twin trends have profoundly upset the very architecture of US governance.

${ }^{108}$ Joint Resolution to Authorize the Use of United States Armed Forces Against Those Responsible for the Recent Attacks Against the United States, Pub. L. No. 107-40, \& 2(a), 115 Stat. 224 (2001).

109 Authorization for Use of Military Force Against Iraq Resolution of 2002, Pub. L. No. 107-243, 116 Stat. 1498 (2002).

${ }^{110}$ See, e.g., D. Byman, "Comparing Al Qaeda and ISIS: Different goals, different targets" (prepared testimony before the Subcommittee on Counterterrorism and Intelligence of the House Committee on Homeland Security), April 29, 2015, https://perma.cc/L7UH-KS4Z.

${ }^{111}$ See DaCosta v. Laird, $44^{8}$ F.2d 1368 (2d Cir. 1971); see also Koh, The National Security Constitution.

${ }^{112}$ See J. Ely, War and Responsibility: Constitutional Lessons of Vietnam and Its Aftermath (Princeton, NJ: Princeton University Press, 1993). Indeed, during the Korean War, Truman administration officials referred to the conflict as a "police action," despite the deployment of more than five million US troops to the region. 


\section{THE INTERNATIONAL HUMANITARIAN LAW CRIMINAL}

\section{ACCOUNTABILITY FRAMEWORK}

The combined impact of unmanned weaponry and military privatization not only destabilizes the constitutional and statutory separation of powers arrangements enshrined in US law, but also unsettles the framework of international humanitarian law, also known as the law of armed conflict. In particular, increasingly autonomous weaponry and growing privatization tend to spread responsibility for decisionmaking across a larger number of actors who do not fit neatly within either a military command structure or an ordered bureaucracy. Thus, as multiple actors work together to gather intelligence, make targeting decisions, and deploy weapons, the authority and responsibility for decisions involving violence are diffused and fragmented. Accordingly, if it turns out that the use of a weapon violates IHL, it is far more difficult even to determine who is responsible. In this new world of fragmented authority, our existing legal and bureaucratic processes are inadequate to provide sufficient mechanisms of accountability. As a result, we face potential difficulties in trying to ensure compliance with IHL norms.

Scholars and policy-makers have debated extensively whether the use of unmanned and autonomous weapons threatens fundamental IHL principles. For example, some have argued that the asymmetric harm such weapons can inflict flouts core principles of humanity that undergird IHL, or that the promise of precision that such weapons offer may be overstated. ${ }^{113}$ In contrast, others have contended that such weapons are potentially more precise than human beings who pull triggers and might therefore provide an opportunity for more humane warfare, stripped of the irrationality, hot-blooded decision-making, and emotional toll of the battlefield. ${ }^{114}$ Such weapons, according to this argument, might paradoxically lead to better effectuation of the IHL principles that lie at the heart of that body of law, such as distinction and proportionality. ${ }^{115}$

Still others have emphasized that, regardless of whether or not unmanned and autonomous weapons might better implement substantive IHL principles, autonomy itself can pose serious problems for accountability. ${ }^{116}$ Perhaps most

${ }^{113}$ See, e.g., M. Wagner, "The Dehumanization of International Humanitarian Law: Legal, Political, and Ethical Implications of Autonomous Weapons Systems" (2014) 47 Vanderbilt Journal of Transnational Law 1371-424; Docherty, "Losing Humanity."

${ }^{114}$ See, e.g., U.N. Report of the Special Rapporteur, Heyns; M. Waxman and K. Anderson, "Law and Ethics for Autonomous Weapon Systems: Why a Ban Won't Work and How the Laws of War Can," The Hoover Institution, April 13, 2013, https://perma.cc/C4UA-7DJN; R. Arkin, "The Case for Ethical Autonomy in Unmanned Systems" (2010) 9 Journal of Military Ethics 332-41, https://perma.cc/6K99-248D; see also D. Cohen, "Drones off the Leash," U.S. News, July 25, 2013, https://perma.cc/XT35-LB2H.

${ }^{115}$ For an excellent overview of the debate about autonomous weapons and a moderate approach to the issue, see J. Vilmer, "Terminator Ethics: Should We Ban 'Killer Robots'?, Ethics \& International Affairs (March 23, 2015), https://perma.cc/U6QD-TMDE.

${ }^{116}$ See Wagner, "The Dehumanization of International Humanitarian Law." 
significantly, these systems threaten the framework of individual criminal responsibility that undergirds all of IHL. From the Nuremberg trials of Nazi war criminals to proceedings before the International Criminal Court, a fundamental aspect of international humanitarian law is that perpetrators will be held individually responsible for egregious violations of the law of war that constitute war crimes. While such prosecutions are rare, they serve as core sanctions that ensure compliance with this body of law.

But whether it is individual criminal punishment or some other form of accountability, unmanned autonomous weapons pose problems for this framework. As a number of scholars have pointed out, in the case of truly autonomous systems, who will be responsible for the decision to strike? ${ }^{117}$ In 2012, partly due to accountability concerns, the United States issued a temporary ban on fully autonomous systems. ${ }^{118}$ Subsequently, policy-makers and scholars gathered at the United Nations in 2015 to discuss these issues. ${ }^{119}$

Meanwhile, a rich debate has also emerged over the impact of military and security privatization on international humanitarian law and policy. ${ }^{120}$ For example, some have called for an outright ban on the practice. ${ }^{121}$ Others, including myself, have advocated for new means of regulation, such as the use of contracts and publicprivate accreditation regimes, that attempt to bring the public values embedded in IHL into this newly privatized realm. ${ }^{122}$ Without such reforms, existing systems of accountability and oversight will be weak and ineffectual.

Yet few, if any, scholars have addressed the combined force of increasingly autonomous weaponry and privatization. Paired together, these trends significantly enhance the accountability and oversight problems each poses separately. Thus, my

${ }^{117}$ Ibid.; J. Thurnher, "Examining Autonomous Weapon Systems from a Law of Armed Conflict Perspective," in H. Nasu and R. McLaughlin (eds.), New Technologies and the Law of Armed Conflict (Den Haag, the Netherlands: T. M. C. Asser Press, 2014), p. 225; M. Sassòli, "Autonomous Weapons and International Humanitarian Law: Advantages, Open Technical Questions and Legal Issues to Be Clarified" (2014) 9o U.S. Naval War College, International Law Studies 308; see also B. Keller, "Smart Drones," The New York Times, March 16, 2013, www.nytimes.com/2013/03/17/opinion/sunday/keller-smart-drones.html.

${ }^{118}$ Department of Defense, Autonomy in Weapon Systems, DoD Directive 3000.09, Washington, DC: U.S. Department of Defense, 2012, https://perma.cc/NLG5-ETGS.

119 United Nations Meeting of Experts on Lethal and Autonomous Weapons Systems (April 13-17, 2015), https://perma.cc/ZC4Q-PMPJ.

${ }^{120}$ See generally Avant, The Market for Force; L. Cameron and V. Chetail, Privatizing War: Private Military and Security Companies under International Law (Cambridge: Cambridge University Press, 2013); Dickinson, Outsourcing War and Peace; McFate, The Modern Mercenary; Singer, Corporate Warriors; International Committee of the Red Cross, The Montreux Document: On pertinent legal obligations and good practices for States related to operations of military and security companies during armed conflict (Geneva: International Committee of the Red Cross, 2009), https://perma.cc/6THJ-XV68.

${ }^{121}$ See, e.g., S. Percy, Mercenaries: A History of a Norm in International Relations (Oxford: Oxford University Press, 2007).

${ }^{122}$ Dickinson, Outsourcing War and Peace; L. Dickinson, "Regulating the Private Security Industry: The Promise of Public/Private Governance" (2013) 63 Emory Law Journal 417-54. 
goal in this section is to break new ground by scrutinizing how these two phenomena intersect and to assess how that intersection could impact the potential for imposing accountability under IHL when serious violations occur.

Although much could be said about multiple forms of accountability, my focus here will be on individual criminal responsibility. In particular, my contention is that both privatization and the use of increasingly autonomous weapons fragment decision-making and bring it outside the ordinary bureaucratic chain of command. This fragmentation makes accountability harder to impose, because it becomes very difficult to hold individuals responsible for serious harms that occur. Thus, the use of these weapons by a military that has also outsourced multiple functions to private contractors presents distinct problems that add up to more than the combined impact of each of the two trends. In other words, the whole of the problem very likely is worse than the sum of its parts.

\section{A Autonomous Weaponry and Individual Criminal Accountability}

A growing body of scholarship highlights the difficulties in holding individuals criminally responsible for uses of unmanned and autonomous weapons that lead to significant violations of IHL. For example, Markus Wagner has observed that, if these weapons can effectively make decisions such as engaging in target selection, it will be very difficult to determine which individuals to hold responsible for those decisions, let alone fit the humans' decisions into existing doctrinal frameworks. ${ }^{123}$ If a soldier is monitoring the operation of a weapon that goes on a rampage and the soldier fails to stop it, should he or she be held responsible? Or does responsibility lie with the programmer who made it possible for the weapon to act in this way? Or the manufacturer? Or possibly even the military commander who approved the use of the weapon in the first place?

In a seminal article, Rebecca Crootof explained that a significant aspect of the problem flows from the doctrine of international criminal law itself, in particular the intent requirement for most war crimes. ${ }^{124}$ War crimes usually must be committed "willfully," which means that the accused must have either acted with the intent to commit a violation or acted recklessly. Thus, if autonomous weapons were used to commit war crimes, a prosecutor might demonstrate the requisite intent by proving that a software engineer had deliberately programmed the weapon to target civilians, or a commander had ordered them to be used in such a manner. But Crootof emphasizes that these are the "easy cases" and instead focuses on the hard case of "whether anyone might be accountable in the more complicated situation where no individual acts intentionally or recklessly, but an autonomous weapon system

${ }^{123}$ See Wagner, "The Dehumanization of International Humanitarian Law."

${ }^{124}$ See R. Crootof, "War Torts: Accountability for Autonomous Weapons" (2016) 164(6) University

of Pennsylvania Law Review 1347-402. 
nonetheless takes action that constitutes a serious violation of international law."125 Assuming that "no one intended the violation or acted recklessly, no one can be held directly liable." ${ }^{\prime 26}$ Because of these difficulties, Crootof does not support criminalizing negligence, arguing that civil responsibility in tort is a more appropriate mechanism of accountability in such cases than criminal responsibility.

International criminal law does contain multiple doctrines that provide criminal accountability for participants in war crimes who do not actually pull the trigger. For example, the doctrine of command responsibility permits the imposition of liability on persons with authority over the acts of subordinates in some circumstances. The doctrine of aiding and abetting reaches those who may assist in the commission of a war crime. And the doctrines of complicity and joint criminal enterprise sweep broadly to cover all of those who agree to commit war crimes. These doctrines do not necessarily require all participants to have intended to commit war crimes.

Yet, as Heather Roff points out, these doctrines are premised on the notion that there is at least one individual who did possess the requisite intent, an observation that Crootof makes as well. ${ }^{127}$ Thus, under the doctrine of command responsibility, a superior can be punished for the war crime of a subordinate if that superior has actual or constructive knowledge of the crime and effectively controls the subordinate. In other words, he or she need not have intended for the crime to be committed, but at least the subordinate must have possessed the requisite intent. In the case of a superior in charge of an autonomous weapon, it cannot be fairly said that the autonomous weapon possesses the requisite intent. Thus, merely negligent supervision could not clearly justify criminal punishment under a theory of command responsibility. ${ }^{128}$

125 Ibid., 1377.

${ }^{126}$ Ibid.

${ }^{127}$ H. Roff, "Killing in War: Responsibility, Liability and Lethal Autonomous Robots," in A. Henschke et al. (eds.), Routledge Handbook of Ethics and War: Just War Theory in the 21st Century (New York: Routledge Press, 2013); see also Crootof, "War Torts."

${ }^{128}$ Jens David Ohlin has argued that international criminal law can nonetheless provide a framework for accountability with respect to the use of semi-autonomous and autonomous weapons. He observes that the origins of the command responsibility and other doctrines emerging out of the Nuremberg trials are premised on the notion of actions in a bureaucratic context, in which the bureaucracy itself is the instrument of harm. He suggests that the critical element of criminal responsibility of the commander in this context is control, not whether the subordinate possesses the requisite intent. J. Ohlin, "The Combatant's Stance: Autonomous Weapons on the Battlefield," (2016) (92) Int'l Leg. Stud. 1-30. The challenge for Ohlin's view is that the concept of effective control in the context of ordinary bureaucracy is not easily applied to those operating autonomous weapons. Even in the case of semi-autonomous weapons, meaningful human control will not always be possible, particularly when systems are complex and involve multiple components. Moreover, Ohlin acknowledges that while the doctrine of command responsibility does not necessarily require commanders to intend harm, at a minimum a showing of recklessness is required. But in many cases involving autonomous or even-semi-autonomous weapons, there may be no human being within the bureaucracy who could be deemed to be reckless. 
The problem depends in part on how one defines "autonomous," which is the source of significant debate among scholars and policy-makers. The challenge of criminal accountability is particularly acute for fully autonomous weapons that can engage in independent decision-making. No such weapons are in operation, and the technology to implement this kind of autonomy in weapons systems may still be many years away. Nonetheless, the problem could still arise for a semi-autonomous system, as we will see below.

\section{B Privatization and Individual Criminal Accountability}

Privatization also undermines criminal accountability for war crimes, but in a slightly different way. When governments turn over military and security functions to armed contractors and authorize them to use force, there is, of course, a risk that those contractors could abuse the responsibility and commit criminal acts. To be sure, under well-established doctrines of international criminal law dating back to the Nuremberg trials of Nazis in the aftermath of World War II, non-state actors can be prosecuted for serious violations of the law of war during an armed conflict. As I have written elsewhere, ${ }^{129}$ the mere fact that these contractors are private actors does not insulate them from war crimes prosecution.

Yet the fragmentation of decision-making within bureaucracies has long presented hurdles for such prosecutions. Notions of due process and fundamental justice in criminal proceedings tend to rest on principles of individual criminal responsibility and the opportunity to individually defend oneself in a fair proceeding. Guilt by association or group membership is antithetical to these principles. Yet, while individuals commit war crimes, in modern society they often do so within a much broader organizational context: as members of militaries, civilian governmental departments, private corporate contractors, terrorist organizations, or other groups. Thus, the person who pulls the trigger is often not the decision-maker. Subordinates may sometimes go rogue and act on their own, but at other times, they may be doing the dirty work for an organization's leaders. At the same time, those leaders may not know of the subordinates' specific actions, making it difficult to impose command responsibility. And, in between group leaders and trigger-pullers, other members of an organization may take small steps that facilitate or contribute to the commission of criminal acts; for example, a secretary may sign an order requisitioning the weapons used to target civilians, a budgeting official may allocate funds to purchase such weapons, and so on.

As noted above, international criminal law contains multiple doctrines that allow courts to convict individuals for war crimes and other atrocities even when they contribute to the commission of those crimes due to their role in larger organizations. Nevertheless, applying these doctrines remains fraught with difficulty. Perhaps

${ }^{129}$ Dickinson, Outsourcing War and Peace. 
the least controversial of the doctrines is the theory of command responsibility, whereby a superior with authority can be held responsible for the acts of a subordinate. Because of the intent requirement for both the subordinate and the superior, command responsibility fits most cleanly into traditional liberal conceptions of individual criminal responsibility. International courts and tribunals have deployed the doctrine to hold both military and civilian leaders responsible, and they have determined that formal legal authority is not necessary if the individual superior in question exerts de facto control over a subordinate.

Yet, privatization makes it far more difficult to impose even this less controversial version of criminal responsibility on the government actors who supervise contractors. This is because contractors often fall outside the military or bureaucratic chain of command, making it far more difficult to demonstrate that government actors exercised the requisite degree of authority and control to be criminally responsible themselves. For example, the fact that government actors may have generally supervised the large government contracts under which contractors operate would probably not be sufficient to impose command responsibility.

More broadly, the doctrine of command responsibility has never been able to comfortably encompass cases of fragmented responsibility, in which multiple actors together commit a wrong even if no one individual in the group intends the harm. Probably the most controversial and notable effort to address the problem of groupbased contributions to war crimes took place during the prosecution of major Nazi war criminals before the International Military Tribunal at Nuremberg (IMT). There, prosecutors tackled the problem head-on by seeking to designate Nazi groups such as the Gestapo and the SS as criminal organizations. ${ }^{130}$ Prosecutors had hoped to avoid the difficulty of proving the criminal responsibility of each individual within these organizations by persuading the IMT to deem these organizations criminal. Such a designation would have allowed subsequent proceedings to convict individuals for mere membership in these organizations. Relying on charter provisions that opened the door to organizational accountability, ${ }^{131}$ the prosecution essentially argued that the entire Nazi state was a criminal operation: "We shall ... trace for you the intricate web of organizations which these men

${ }^{130}$ In addition to charges against twenty-two individual defendants, the prosecution alleged that six organizations constituted criminal organizations due to their role in perpetrated acts of aggression, war crimes, and crimes against humanity, the three crimes within the jurisdiction of the tribunal. The six organizations were the Leadership Corps of the Nazi Party, the Gestapo, the SS, the SA, the Reich Cabinet, and the general staff and high command of the Nazi Party.

${ }^{131}$ The Charter of the Tribunal specifically provided that "[a]t the trial of any individual member of any group or organization the Tribunal may declare (in connection with any act of which the individual may be convicted) that the group or organization of which the individual was a member was a criminal organization." Charter of the International Military Tribunal, August 8, 1945, 59 Stat. 1546, 82 U.N.T.S. 284 \& II, art. 9. The charter also specified that, in subsequent proceedings before national courts of states parties to the charter, individuals could be tried for mere membership in organizations deemed criminal by the IMT. Ibid., art. 10. 
formed and utilized to accomplish these ends. We will show how the entire structure of the offices and officials was dedicated to the criminal purposes and committed to the use of criminal methods planned by these defendants and their coconspirators." ${ }^{32}$

The IMT rejected the prosecution's broad theories, however, and took a much more limited approach to the question of the organizations' criminality. Although the court did not throw out the conception of organizational criminality altogether, it defined quite narrowly the groups that could be deemed criminal, and concluded that only three of the six organizations qualified. ${ }^{133}$ Moreover, the IMT struggled with the implications of a process that might lead to guilt by association and emphasized that "innocent persons" should not be punished. ${ }^{134}$ Thus, the IMT concluded that a group could be deemed criminal only in the limited circumstances when it could be proved that group members were "bound together and organized for a common purpose" and the group was "formed or used in connection with the commission of crimes denounced by the Charter." 135 The IMT further restricted the circumstances in which individuals could be convicted for membership in such associations, essentially crafting a requirement for an individualized finding of mens rea for each person accused of membership in a criminal organization. ${ }^{136}$ Thus, while the tribunal recognized that group-based liability might be useful because of the challenges of bringing charges against each individual within a large organization, ${ }^{137}$ the court was nevertheless reluctant to accept a broad theory of organizational responsibility because of the risks to fundamental due process in criminal prosecutions.

The Nuremberg Tribunal's foray into organizational accountability has largely been viewed as a failure, certainly in comparison to its highly influential development of the substantive principle of individual criminal responsibility for war crimes

${ }^{132}$ Trial of the Major War Criminals Before the International Military Tribunal, Nuremberg, November 14, 1945 - October 1, 1946, Second Day, Wednesday, November 21, 1945, Morning Session, p. 104 (1947). For a detailed account of the case against the Nazi organizations at Nuremberg, see D. Fraser, “(De)Constructing the Nazi State: Criminal Organizations and the Constitutional Theory of the International Military Tribunal" (2017) 39(1) Loyola of Los Angeles International and Comparative Law Review 117-86.

133 Judgment of the International Military Tribunal for the Trial of German Major War Criminals, pp. $67-80$ (1946).

134 Ibid., p. 67.

135 Ibid.

${ }^{136}$ The tribunal noted: "[It] should exclude persons who had no knowledge of the criminal purposes or acts of the organization and those who were drafted by the State for membership, unless they were personally implicated in the commission of acts declared criminal ... in the Charter as members of the organization. Membership alone is not enough to come within the scope of these declarations." Ibid.

${ }^{137}$ For example, the IMT stated that "[w] here an organization with a large membership is used for such [criminal] purposes, a declaration [of criminality] obviates the necessity of inquiring as to its criminal character in the later trial of members who are accused of participating through membership in its criminal purposes and thus saves much time and trouble." Ibid. 
and crimes against humanity. Indeed, the tribunal's efforts to wrestle with the problem of organizational accountability highlights what David Luban has described as a core challenge of modern life: "the problem of moral responsibility in bureaucratic settings." 138

Drawing on the work of Robert Conot and Hannah Arendt, Luban notes that part of the horror of Nazi atrocities stemmed from the organizational setting in which they took place. These were not the acts solely of evil masterminds or bloodthirsty gangsters. Rather, "through the fragmentation of authority and tasks, it was possible to fashion a murder machine." ${ }^{139}$ Luban cites Conot as observing that "[t]housands of people were involved, but each considered himself nothing but a cog in the machine and reasoned that it was the machine, not he, that was responsible." 140 In Luban's view, this "bureaucratic irresponsibility" is the "moral plague of modern life," and he refers to Hannah Arendt's insight that bureaucracy is "the latest and perhaps most formidable form of ... dominion" because it is "the rule of an intricate system of bureaus in which no men, neither one nor the best, neither the few nor the many, can be held responsible, and which could be properly called rule by Nobody." "141

Luban believes that the bureaucratic Nazi machine does not ultimately represent the most difficult version of this problem, however, because many of the participants could be said, at a minimum, to be "willfully" blind to their role. That is, they fit within relatively traditional conceptions of moral culpability and recognized criminal law concepts. To the extent that individual Nazi bureaucrats did not know about the final solution, for example, it was because they deliberately shielded themselves from that knowledge and therefore possessed some degree of intent. As Luban puts it,

the top Nazis may not have known what the inside of a death camp looked like, but they knew what the code name "Final Solution" meant. Lower level flunkies such as Ivan the Terrible, the notorious executioner at Treblinka, may not have known why they were gassing Jews, but they could not help but know that mass killing was mass murder. Whatever blindness such people allege is willful blindness. ${ }^{42}$

The more difficult situation in which to assign moral culpability and impose criminal legal responsibility, however, is one in which each of the cogs in a bureaucratic machine is truly ignorant of the commission of atrocities. Such a situation may well be presented by the combination of automation and contracting.

${ }^{13^{8}}$ D. Luban, Legal Modernism: Law, Meaning, and Violence (Ann Arbor: University of Michigan Press, 1994), p. 362.

139 Ibid., p. 363 (quoting R. Conot, Justice at Nuremberg [New York: Basic Books, 1983], pp. 210-11).

${ }^{140}$ Ibid. (quoting Conot, Justice at Nuremberg).

${ }^{141}$ Ibid. (quoting H. Arendt, On Violence [Orlando, FL: Harcourt Publishing, 1970], p. 38).

$14^{2}$ Ibid., p. 372. 
Individual contractors, operating outside of military hierarchies, are each responsible for one aspect of a drone's construction, maintenance, and operation. Unlike the "willful blindness" described by Luban, these individuals may well be entirely ignorant of the larger purpose for which the drones are employed. Thus, automation and contracting together immensely complicate the search for moral and legal accountability within bureaucratic settings.

Subsequent proceedings before international criminal tribunals demonstrate the tensions inherent in the effort to impose criminal responsibility based on group membership, along with the challenges posed by war crimes committed within a bureaucratic setting more broadly. Arguing before these tribunals, prosecutors have used a variety of doctrines, including command responsibility, aiding and abetting, and joint criminal enterprise, to impose criminal responsibilities on individuals implicated in the commission of war crimes and other mass atrocities due to their roles in large, complex organizations. Yet most of these doctrines, as in the proceedings before the Nuremberg Tribunal, have retained a relatively traditional conception of individual criminal responsibility that is based on individual mens rea and individual culpability.

Thus, to the extent that such doctrines are predicated on individuals intentionally agreeing to and supporting criminal acts, they reflect a more traditional conception of individual responsibility. And when these doctrines have been applied more broadly and have attempted to sweep in a broader array of actors who may not have intended to commit or may not have truly participated in the underlying crime, critics have charged that these doctrines are antithetical to fundamental principles of individual criminal responsibility. For example, Allison Danner and Jenny Martinez have argued that these doctrines, "if not limited appropriately, have the potential to lapse into forms of guilt by association, thereby undermining the legitimacy and the ultimate effectiveness of international criminal law." ${ }^{143}$ With respect to joint criminal enterprise in particular, Danner and Martinez argue that international judges "should require that prosecutors demonstrate that each individual charged under a joint criminal enterprise theory made a substantial contribution to the fulfillment of the common objective of the enterprise" and that any form of the doctrine that tolerates a "reduced mens rea should not be used for specific intent crimes." ${ }^{144}$ With respect to command responsibility, they argue that "something more than ordinary negligence should remain the touchstone for criminal responsibility." 145

Although these arguments make perfect sense from the traditional criminal law framework perspective, they may render many acts undertaken within bureaucratic institutions unaccountable, even when those acts represent tiny cogs in a

\footnotetext{
${ }^{143}$ A. Danner and J. Martinez, "Guilty Associations: Joint Criminal Enterprise, Command Responsibility, and the Development of International Criminal Law" (2005) 93(1) California Law Review $77^{-170}$ at 79 .

${ }^{144}$ Ibid., at 79 .

${ }^{145}$ Ibid.
} 
bureaucratic machine that is committing grave atrocities. Moreover, in a world of increasingly automated weaponry and increasing military privatization, assigning traditional individual criminal responsibility may only become more difficult over time.

\section{The Combination of Autonomous Weaponry and Privatization}

When an autonomous machine is injected into a bureaucratic system and then private contractors are hired to help operate it, individual criminal responsibility becomes even more challenging and problematic. Lethal force at the robotic hands of the autonomous weapon presents an even grimmer vision of Arendt's "rule by no one," probably far beyond even Arendt's already dystopian imagination. Indeed, when information necessary for targeting decisions is sifted by private contractors, then the fragmentation of decision-making no longer even occurs inside the government, but now falls outside the bureaucracy itself. And when those contractors feed information into an autonomous system that is engaging in the targeting, the problem magnifies exponentially.

The threat is perhaps easiest to perceive when considering fully autonomous weapons systems that move, detect threats, and engage targets based on predetermined criteria. But because no fully autonomous weapons systems are currently operational (and some commentators question whether such technology is imminent) and because many governments have, for now, said they will not use them, I will focus instead on partially autonomous systems. These systems are preprogrammed to detect and strike certain categories of targets, but usually a human being remotely oversees the operation and can override the automated system.

One such example is the Israeli Harpy, which, when launched by a human operator, can detect an enemy radar system and autonomously dive-bomb and strike that target. If the Harpy killed a large number of civilians in a manner that could be said to violate the principle of proportionality, who could or should be held responsible? The human being with the responsibility to override the weapons system? The commander of the territory where the weapons system was deployed? The individuals who set policy for using the technology? The individuals who drafted the targeting criteria? The engineers who designed the weapons system to apply the targeting criteria? Anyone who supplied intelligence that fed into the weapons system and formed the basis for target selection? In the case of even partially autonomous systems, it is difficult to locate a responsible human agent. ${ }^{146}$

Only human beings can be held criminally responsible for actions. But in this case, there is no clear human actor who bears full responsibility. Some of the people in the chain listed above might plausibly be tried, and the governments of the

${ }^{146}$ See Wagner, "The Dehumanization of International Humanitarian Law"; see also Roff,

"Killing in War." 
United States and the United Kingdom have said that the last human to make a decision regarding the operation of the weapon should be held responsible. Yet arguably this is inadequate, because no one person truly can be said to make that decision. As discussed above, the doctrine of command responsibility allows for superiors in the chain of command to be tried, but that theory is premised on the notion that the human being who actually pulled the trigger could also be tried for the same crime. Yet here there is no human being who can accurately be said to have pulled a trigger.

At its root, the problem is not the mere lack of a human agent. It is that autonomy - even partial autonomy - fragments the decision-making process, spreading the decision across a large number of individuals, thereby making it much harder to hold any one person responsible. And, of course, adding contractors to the mix further diffuses and breaks up the decision-making process. For example, as previously discussed, with many remotely operated weapons systems, such as drones, contractors are involved in supplying intelligence that leads to target selection as well as occasionally calling in targets from the ground. Is the intelligence-gathering that determines the targeting decision itself a targeting decision that implicates criminal responsibility? And does it matter that the contractor is not a state actor? In short, the existing legal doctrine is not equipped to cope with criminal responsibility in the case of automated and outsourced weapons systems.

\section{CONCLUSION}

The purpose of this chapter has been to highlight the profoundly destabilizing impact of unmanned and autonomous weapons systems and privatization on both domestic and international law regulating the use of force abroad. These trends have emerged concurrently, and together they disrupt existing legal frameworks more than each would do separately. On the domestic front, unmanned and autonomous weaponry and privatization potentially alter the balance of power between the president and Congress by buttressing legal arguments that the use of force can be limited in ways that do not require congressional approval. Meanwhile, these trends also work together to put pressure on international humanitarian law, because they fragment and diffuse decision-making, thereby complicating efforts to impose individual accountability. Accordingly, it will be a core challenge for law and governance in the twenty-first century to evolve new legal regimes and new mechanisms of oversight and accountability to respond to the radically changing face of armed conflict. 
